\title{
Global production networks and natural resource extraction: adding a political ecology perspective
}

\author{
Felix M. Dorn and Christoph Huber \\ Institute of Geography, University of Innsbruck, Innsbruck, Austria \\ Correspondence: Felix M. Dorn (felix.dorn@student.uibk.ac.at)
}

Received: 27 January 2020 - Revised: 18 May 2020 - Accepted: 1 June 2020 - Published: 23 June 2020

\begin{abstract}
The article examines how to adapt the global production network (GPN) approach to situations of natural resource extraction. Based on an integration of a political ecology perspective into GPN research, we exemplarily apply the GPN framework to the primary sector. Based on extensive qualitative fieldwork regarding Argentine lithium mining and Brazilian soy agribusiness we illustrate that particularly a political ecological environmental perspective allows for a more nuanced and critical analysis of ambiguous local development outcomes. While from a purely economic development perspective in both cases the economic activity (integrated into GPNs) is celebrated as an imperative economic growth driver, our framework helps identify the emergence of unilateral dependencies, a decline of social autonomy and an unequal distribution of environmental risks.
\end{abstract}

\section{Introduction}

Starting with the discovery of Cerro Rico, close to Potosí, Latin America has historically been reduced to its role as a supplier of raw material. Today, in many respects the continent's colonial heritage continues (to show) in the global economic system (see Machado Aráoz, 2014; Galeano 2015). Independent of the respective governments' ideological orientation, the export of mining and agricultural products still perpetuates a central pillar of national development strategies. The extractive boom in the early 2000 s coincided with a period of dominance of leftist governments and further deepened the re-primarization of national economies. This concern has been widely discussed by academic intellectuals in the context of neo-extractivism. In the recent past, conservative and right-wing governments have taken over in some countries of Latin America, whereby the strategy of exportoriented extractivism has been further enhanced.

Such extractivist development models are thickly embedded in global production networks (GPNs). The framework conditions of natural resource extraction at the local level are largely shaped at the national level. Moreover, extractivism is highly triggered by a global context dependent on global resource demand patterns and inter-firm organization of production. The GPN approach builds upon three key concepts: value, power and embeddedness. In the following, we exem- plarily focus on the conceptual category of value capture and combine it with a political-ecological perspective on socialecological consequences in order to critically analyze development outcomes of resource extraction embedded in GPNs.

Development outcomes as a consequence of uneven access to resources, as well as the unequal distribution of environmental risks, are central concerns in Political Ecology (PE). In PE, development issues are usually approached through structural political-economic analysis, whereby (inter-)firm organization is not considered of central developmental significance. The GPN approach, however, explicitly draws attention to the relevance of firms (and the social network of economic and noneconomic actors in which they are embedded) and the (global) organization of production for local economic development outcomes. Although specific GPNs are formed around resource extraction, with only a few exceptions GPN analysis has not been applied to extractive contexts (e.g., Bridge, 2008; Radhuber, 2015; Schmitt and Schulz, 2016). Bearing in mind the developmental significance of resource extraction in Latin American history and the global production networks in which the extractivist activities are embedded, the GPN approach seems to be a particularly useful concept. At the same time, we note that the GPN approach lacks the means for theorizing and conceptualizing social-ecological issues. Particularly in regard to 
resource extraction, which entails direct human and nature relations, observing the social-ecological effects of GPN dynamics that shape developmental consequences seems important. In a context of resource extraction and structural power imbalances between actors in global-national-local relations, political ecologists point out that extractivism implies significant ecological consequences and that the economic benefits of the aforementioned resource boom often contrast with socio-ecological costs at the local level (Göbel, 2013). We therefore argue that a political-ecological perspective on global production networks can be very fruitful for broadening the GPN approach, especially when applied to GPNs based on natural resource extraction. By analyzing the cases of lithium mining in the Argentine Andes and soy agribusiness in the Brazilian transition zone between the Cerrado and the Amazon biome, we point out and discuss the strengths of GPN analysis for extractive contexts.

\section{Conceptual approach: applying global production networks to extractive contexts}

\subsection{Global production networks}

The global production network (GPN) approach is usually accredited to the so-called Manchester School, a working group of the University of Manchester (Henderson et al., 2002; Coe et al., 2004, 2008). Starting from the critique regarding the global value chain and global commodity chain approaches (see, for example, Gereffi and Korzeniewicz, 1994), Henderson et al. (2002) introduce a framework that should "refocus attention on the social circumstances under which commodities are produced and consumed". In order to reflect the complexity of value-added processes more realistically, the GPN approach replaces the linear chain metaphor with the network concept. Besides the network structure, central enhancements are a dynamic connection between different actors, actor groups and spatial scale levels (multi-actor and multi-spatial). It includes noneconomic actors, such as provincial and national institutions, NGOs, indigenous communities, civil society organizations and labor groups, and takes into account the broad political economic context (Kister, 2019). The GPN approach aims at developing a relational, process-oriented and spatial view of production. Thereby, it is recognized that networks "constitute and are reconstituted by the economic, social and political arrangements of the places they inhabit" (Henderson et al., 2002). Emphasis in academic GPN literature was mainly put on the role of the state and specific conflicts so far. However, extractive processes are strongly globalized activities. This is why the GPN approach is an appropriate tool for analyzing global impacts on the local level, as well as a particularly suitable framework to explain patterns of uneven development (Yeung and Coe, 2015). In this context, the global in GPN helps to locate a GPN "within the 'transnational space' that is constituted and structured by transnational elites, institutions, and ideologies" (Levy, 2008:945).

The disparate control over production steps, extraction sites, and linkages between economic and noneconomic actors of the network unavoidably produces inequalities. Based on the three principal conceptual categories value, power and embeddedness, the GPN approach not only provides a toolkit for decoding complex economic, institutional and social local-global interplays but also for analyzing power relations and interactions between the economic and noneconomic actors involved. The conceptual category value allows for a differentiation between the initial creation of value by generating different forms of rent, its enhancement by realizing value-adding processes and its actual capture (for a more detailed description, see Henderson et al. 2002). However, the concept of value remains anchored in a strict economic notion and does not include social, natural, cultural or spiritual values. In order to have a critical analytical tool to also illuminate forms of undervaluation, value destruction and value transfer, McGrath (2018:511) votes for a more "open expansive understanding of value and valuation" in GPNs. Power in a GPN may originate from or be exercised by corporations, institutions and particular groups (e.g., civil society organizations or employers' associations). The conceptual categories value and power are closely interrelated as the origin and exertion of power determines if and how value can be captured in a specific location. Finally, embeddedness explains how companies, influenced by their respective provenance social and cultural contexts, anchor in certain locations. The three elements outlined above constitute a theoretical framework upon which we can build the analysis of our GPN configurations.

\subsection{A political ecology perspective on GPN}

Political Ecology (PE) is an explicitly critical and political field of research that has spread since the 1970s. An important common starting point for political ecology was the critique of the ontological separation between nature (nonhuman) and society (human) in modernity and in dominant environmental research (Schmitt, 2016). PE rejects both environmental determinism, which explains nature as something that can only be understood by its materiality and its physical processes, and social determinism, such as neo-Malthusian interpretations, which explains resource scarcity as a simple overuse through population growth, thereby ignoring the power relations behind environmental change and resource distribution (Bauriedl, 2016).

Moreover, PE emphasizes that nature or ecology is not an external entity but is inseparably interwoven with the social and is therefore inherently political. The explicitly political position also distinguishes PE from other (preexisting) human-environmental research perspectives within social science (human ecology, cultural ecology, etc.), which remained uncritical to the political and thereby neglected the 
"political-epistemological character" (Leff, 2015) of environmental problems. In contrast, the critical research program of PE combined "the concerns of ecology and a broadly defined political economy" (Blaikie and Brookfield, 1987). Based on neo-Marxist historical materialism approaches, PE began to deal with notions of (capitalist) "production of nature" (Smith, 1984), a concept which emphasizes coevolutionary or metabolic processes between nature and humans through which environment is produced (e.g., Castree, 2000). From this perspective, political ecologists began to analyze how nature becomes a (capitalist-relevant) resource, and how access, appropriation and distribution of resources are organized in light of the prevailing power relations within capitalist societies. The conclusions drawn from such studies point to an unequal distribution of the benefits and costs of environmental change and resource issues, which further result in an amplification of uneven development. While this early PE research was primarily concerned about rural areas of the Global South (Bryant and Bailey, 1997), the research focus has since expanded to a global perspective (see Peet et al., 2011), thereby also including the Global North and urban areas (Swyngedouw, 2004). The integration of a wide range of theoretical-conceptual approaches (such as post-structuralist, postcolonial and postdevelopment approaches, actor network theory, "more-thanhuman" approaches, etc.) and the inclusion of contemporary environmental debates (within science, social movements, international politics, etc.) in PE research interest has vastly expanded the field of research, whereby different perspectives and approaches are pursued and developed in parallel.

Although we take note of the further development of GPN and the broad approaches within PE, we see the potential of an integrated perspective in their respective early uses. While GPN analysis is based on an economic perspective regarding the organization and coordination of inter-firm linkages embedded in specific social networks and territories, it does not entail considerations on environmental issues. Social aspects also remain largely unreflected. Instead, PE examines (uneven) "development" with regard to an unequal distribution of resources and environmental risks. Thereby, PE illustrates the profiteers on the one hand and the negatively affected actors on the other hand. Against this background, especially for the analysis of GPNs based on natural resource extraction, a PE perspective enables the consideration of socio-ecological transformation processes driven by GPN dynamics. We argue that including PE perspectives, with its long tradition on critical environmental research, allows for a more nuanced analysis for a critical examination of organization of inter-firm relations and firm strategies with regard to the socio-ecological impacts.

\subsection{A critical reflection of development}

Both GPN and PE are particularly concerned with (uneven) "development". It is therefore necessary to realize further re- flection on the concept of development. Historically, the idea of development has been based on the attempt of achieving human progress through economic growth (Unceta, 2015). While there already is a large body of academic literature about the apparently counter-intuitive outcome that abundance in natural resources does not necessarily increase the societal level of prosperity (see, for example, Altvater and Mahnkopf, 2007; Altvater, 2013; Bridge, 2008, 2010; Watts, 2008), the actual concept of development is often "taken for granted" (Gudynas, 2016) when regarding natural resource extraction. The importance of this trap should not be underestimated. In this context, José María Tortosa (2011) refers to maldevelopment, a metaphor he uses to explain how the desirable idea of development instead leads to (very few) internationalized winners and (many) local losers. He acknowledges that Mal Vivir (as opposed to the idea of Buen Vivir) is a direct consequence of the current world's system. In this light, economic growth neither equates nor necessarily translates into a higher quality of life, social autonomy or even social justice.

In a Latin American context, following classical development ideas and the international division of labor, this resulted in a strong focus on the extraction and exportation of natural resources. Particularly in the 19th century, in the name of development, indigenous communities were dominated, and large areas were appropriated for resource extraction. On one hand, the ideas of progress and development were used to "civilize" both "savages" and wilderness areas (Gudynas, 2012). In the 20th century, on the other hand, based on the assumption that the export of primary resources is a necessary precondition in order to reinvest revenues into national industrialization, the argument of development provided a strong political basis for legitimacy to valorize supposedly "pristine" territories. Thereby, the continent's colonial heritage provides a breeding ground for the development of extractive activities. The 1980s were dominated by structural adjustment policies and initiated a phase of neoliberalization and privatization (see Coy et al., 2017b). Until the turn of the millennium, the focus on primary products destined for export led to a pronounced re-primarization of many Latin American economies (see Coy et al., 2017b; Dorn and Hafner, 2018).

The emergence of a series of progressive leftist governments since $1999^{1}$ was often accompanied by a strengthening of the state, social programs for fighting poverty and - in some cases - the nationalization of companies. Even though the state ensured the reallocation of benefits towards popular sectors, the focus on exporting agricultural products and mineral resources both further deepened the re-primarization

\footnotetext{
${ }^{1}$ In this context, we refer to the administrations of Luiz Inácio Lula da Silva in Brazil (2003-2011), of Néstor Kirchner and Cristina Fernández de Kirchner in Argentina (2003-2015), of Hugo Chávez in Venezuela (1999-2013), of Rafael Correa in Ecuador (2007-2017), and of Evo Morales in Bolivia (2006-2019).
} 
of the countries' economies and resulted in a strong societal legitimation for extractive activities (see Dorn and Hafner, 2018). In countries like Argentina and Brazil, part of the socalled "Soybean Republic" (Turzi, 2017), soybean cultivation became a major pillar of their economies. Moreover, in the context of technological innovations and a shift towards Green Growth programs, new strategic resources such as lithium became relevant. The extraction and export of primary resources in order to finance social programs has been discussed extensively under the heading of neo-extractivism (see Acosta, 2012; Gudynas, 2012; Svampa, 2016; Coy et al., $2017 \mathrm{~b}$ ). Although the era of progressive governments ended in recent years, it has to be emphasized that neither of the administrations has questioned the rationality of development as growth, the role of exportations and investments, or the appropriation of nature. Development and economic growth were and are still used synonymously.

\section{Study areas and research methods}

Our selected case studies both relate to an extractive context. In a more recent perspective, extraction not only refers to mining, but also includes forms of industrial agriculture. It is argued that large-scale intensive monocultural production of agricultural commodities destined for export with little or no processing has a strong extractivist character (McKay, 2017). The term agri-extractivism (Petras and Veltmeyer, 2014) refers to a type of agriculture that is controlled by transnational agribusinesses and oriented towards global markets (food, feed, biofuel, textile markets, etc.), thereby extracting local resources (land, water, biodiversity, etc.) for transnational capital interest without leaving a significant added value in the region. Therefore, agriculture has ultimately also been included in Latin American neo-extractivist literature (see Gudynas, 2010; Svampa, 2013).

Based on the idea that both agriculture and mining can be considered extractive contexts, we will exemplarily apply the GPN framework to lithium extraction in northwestern Argentina and soy agribusiness in Brazil. Due to the limited space in this article, we will prioritize an analysis of the conceptual category value capture (strongly intertwined with questions of power) and the ecological consequences of extraction. The research regarding lithium extraction is based on extensive 10-month fieldwork realized between February 2018 and August 2019 (84 interviews). With regard to soy agribusiness in Brazil, fieldwork has been conducted during a 1-year research stay in Brazil in 2019 (58 interviews). Both cases are primarily based on methods of qualitative social research. Qualitative interviews have been conducted with relevant actors of the respective production networks (local residents, farmers, indigenous communities, NGOs, lobby groups, politicians, companies, etc.). Moreover, participatory mapping and questionnaires have been conducted to identify social and environmental changes.

\subsection{Lithium extraction at Salar de Olaroz-Cauchari, Argentina}

The Salar de Olaroz-Cauchari is a Salar $^{2}$ (also referred to as saltpan or salt flat) located in the Argentine Andes, more precisely in the department of Susques, Jujuy Province (see Fig. 1). Native people of the area identify themselves as atacameños, a circumstance that underlines the historical reference to the Atacama region, which today constitutes part of Chile. The department of Susques is characterized by a historical marginalization within the national context. Traditional activities are particularly based on transhumant pastoralism of llamas, goats, and sheep; small-scale agriculture; and exchange by the use of caravans, activities that are both of economic and cultural importance. Moreover, these income strategies are often combined with the sale of unskilled labor, non-farming activities such as the production of handicrafts, and small-scale mineral extraction and income from social programs (see Göbel, 2013; Pragier, 2019).

The sudden economic interest in the area as of the late 2000s was triggered by the increasing importance of lithium resources for technological innovations connected with the development of low $\mathrm{CO}_{2}$ emission lifestyles. The attributed importance of replacing the fossil-fuel-based private transport especially led to excessive media attention, speculation and national growth dreams. As lithium is not listed at any stock exchange but traded via bilateral contracts, global players of the automotive industry and chemical companies are looking for direct access to the resource.

Although the Argentine Mining Code regulates mining activities in the country, on the basis of Article 124 of the Argentine Constitution, the original property of resources corresponds to the respective province. This is why every province possesses an individual mining law that regulates the application of the Mining Code (Pragier, 2019). On a national level, mining royalties are limited to $3 \%$. In case a company realizes further industrialization processes, the royalty decreases to $1 \%$. In the case of lithium mining, parts are further processed to lithium carbonate and parts are exported to be being processed to lithium hydroxide in Naraha, Japan.

In the area, lithium is extracted by transnational companies (TNCs) or joint ventures of transnational companies. The company Sales de Jujuy is constituted of the Australian Orocobre $(72.68 \%)$ and the Japanese Toyota Tsusho $(27.32 \%)$ and started to actively extract lithium at the end of 2014. In 2019, Minera Exar, a joint venture of the Canadian Lithium Americas (62.5\%) and the Chinese Ganfeng Lithium (37.5\%) is constructing its evaporation pools and starting extraction. Moreover, South American Salars, the Argentine entity of the Canadian company Advantage Lithium and the Canadian company Millennial Lithium, are realizing exploration studies in the same basin.

\footnotetext{
${ }^{2}$ The Salar de Olaroz-Cuachari are often referred to as the two Salars. This is because Cauchari is located in the immediate South of Olaroz, a narrow continuation of the same water basin.
} 


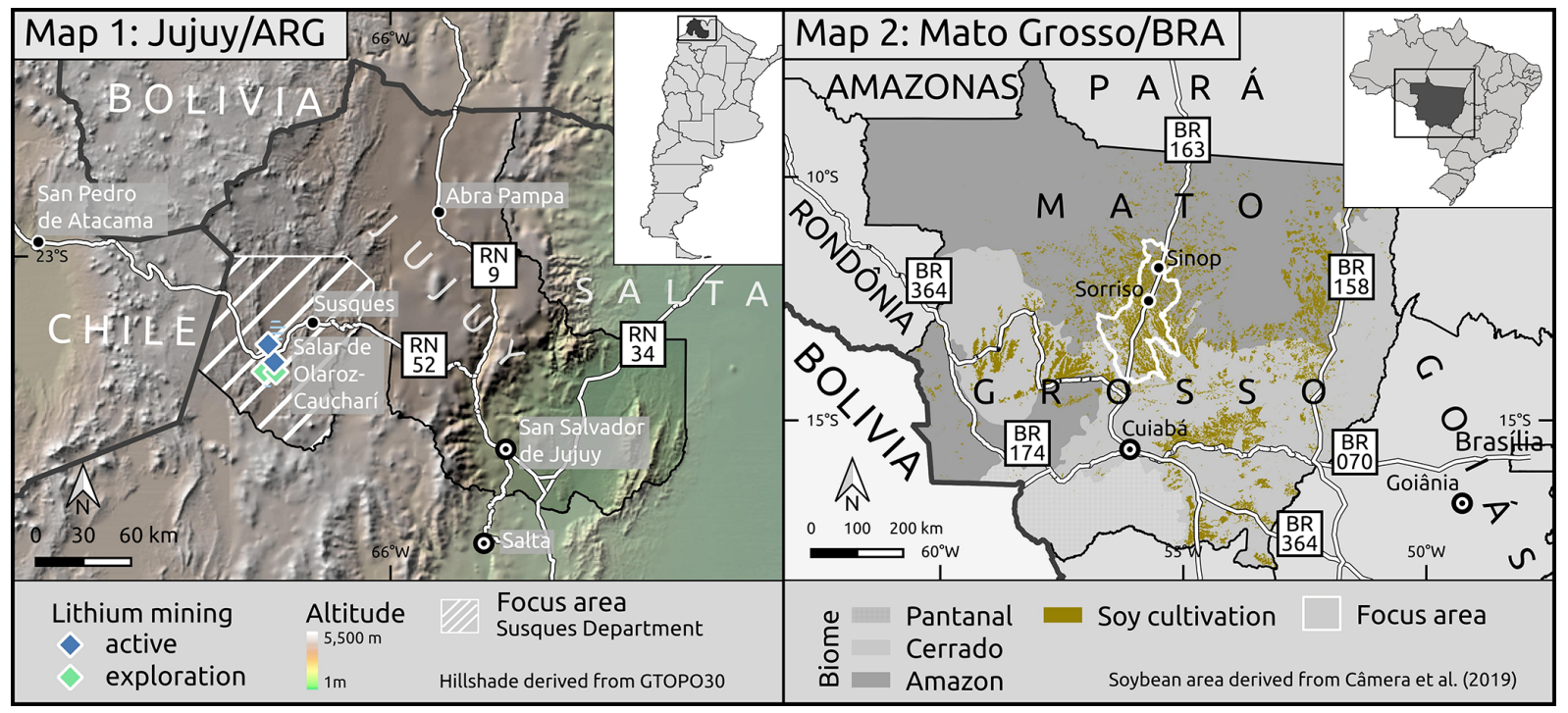

Figure 1. Overview of lithium mining in the department of Susques (Jujuy/Argentina) and soybean cultivation in Mato Grosso, Brazil. Source: own elaboration based on GADM, Instituto Geográfico Nacional de la República Argentina, Câmara et al. (2019), GTOPO30 (USGS), () OpenStreetMap contributors 2019. Distributed under a Creative Commons BY-SA License.

In order to participate more directly in the mining profits, Jujuy founded Jujuy Energía y Minería Sociedad del Estado (JEMSE) in 2011. JEMSE is a semiautonomous state company with 15 employees and the main aim of developing and promoting further mining explorations. Today, JEMSE has a participation of $8.5 \%$ in the Sales de Jujuy project and is about to close its contract of over $8.5 \%$ with Minera Exar. To achieve this $8.5 \%$, JEMSE went into debt with the principal investors. Moreover, for the companies the participation is voluntary and does neither assert a right for voice or vote.

According to Article 75 of the Argentine Constitution, in line with the Indigenous and Tribal Peoples Convention (C169) of the International Labor Organization, it is recognized that indigenous communities participate both in management and control of their natural resources. As a result, in case a community is affected directly or indirectly by a mining project on their territory, the process of prior consultation applies. As of 2009, Sales de Jujuy and Minera Exar have started to contact the 10 indigenous communities of the department of Susques.

In the beginning, the relation between mining companies and communities was mostly characterized by complaisance and goodwill, such as installing wireless networks, enhancing road conditions or providing public transport. At present, Sales de Jujuy has made an official agreement with the community of Olaroz Chico and runs an employment program with all 10 communities of the department of Susques. Instead, Minera Exar has made agreements of easement with the six communities of Huancar, Pastos Chicos, Puesto Sey, Olaroz Chico, Catúa and Susques. These agreements differ according to the relevance of how Minera Exar's Cauchari-
Olaroz project affects the community (directly vs. indirectly).

The communities' principal argument on behalf of lithium mining - and a big part of negotiations, agreements and declarations of intent - is the employment of the local (unskilled) labor force. In 2018 there was an increase of $30.5 \%$ of workers in lithium mining, so that by 2018 Sales de Jujuy had 385 direct employees, 152 from the department of Susques ${ }^{3}$ and an additional 460 employees from contractor companies. Instead, Minera Exar has 188 direct employees and 276 from contractor companies, and South American Salars has 39 direct employees and 112 from contractor companies (Gobierno de Jujuy, 2019). The strong increase in employment has to be considered within the expansion of Sales de Jujuy's Olaroz facilities and Minera Exar's construction of its Cauchari-Olaroz plant, and therefore effective employment in the operation phase remains to be seen. The aforementioned small- and medium-sized enterprise (SME) contractor companies partly stem from the communities themselves, as Sales de Jujuy and Minera Exar have fostered a system of micro-credits for local entrepreneurs. While local SMEs vary widely in size today, while Las Vertientes from Olaroz has 60 employees and offers catering, cleaning, accommodation, and laundry, and Los Tres Hermanos in Susques employs three people, they have the offer of unskilled labor and a strong lack of diversification regarding their client structure in common. However, according to experts in indigenous rights, real prior consultation has never been implemented.

\footnotetext{
${ }^{3}$ Olaroz Chico: 43; Huancar: 21; Susques: 21; Puesto Sey: 13; Pastos Chicos: 12; Coranzulí: 10; El Toro: 10; Jama: 5; San Juan de Quillaques: 5.
} 
There has never taken place a public manifestation of realizing the consultation. It has to be questioned whether the standards for consultation have been accomplished in the case of Olaroz and whether communities have had the necessary participation. Not to oppose themselves, but to have real knowledge and awareness of what is exploited, what are the profits of the companies... well, to stand up for a real discussion (Interviewee 31).

While in 2005 mining products accounted for $9 \%$ of Jujuy's foreign export sales, this number increased to $65 \%$ by 2018 (Gobierno de Jujuy, 2019). With USD 4.3 million (2018; including the bigger lead, silver and zinc mines of Aguilar and Pirquitas), mining royalties may economically be negligible. However, Jujuy's Secretary of Mining emphasizes the importance of employment, indirect income (e.g., small shops and markets), and particularly national and provincial expenses for inputs and services. Due to construction projects, these expenses rose sharply between 2017 and 2018. Sales de Jujuy increased its expenditures by $93 \%$ to USD 137 million, and Minera Exar increased its expenditures by $323 \%$ to USD 55 million. Thereby, $89 \%$ were spent nationally ( $41 \%$ in Jujuy, $48 \%$ in other provinces).

Although this argumentation might indeed increase the provincial coffers, it provides little information about how much value can be captured within the affected region. In all agreements, the communities of so-called direct influence, Olaroz Chico and Pastos Chicos, enjoy priority treatment with direct monetary revenues. Among other communities, this circumstance leads to complaints: "initially we have agreed to work together, to be even. Now the companies look how to arrange some things with some communities. The agreements are more and more invalidated." (Interviewee 77). In several villages, local inhabitants state dissent and conflict between the communities. These conflicts are often inward looking and do not aim against the mining companies. One inhabitant states that "compared to Chile [referring to Consejo de Pueblos Atacameños and their monetary contract with Albemarle] we are not well organized. This is mainly because of Olaroz" (Interviewee 21). Moreover, the growing number of SMEs leads to rivalry between different entrepreneurs, and income disparities provoke conflict and envy within local communities. Besides these arising conflicts, a strong dependence on the companies becomes evident: people do not have alternatives for selling their labor force in the region. Moreover, the majority of SMEs offer their services to just one client. Although the involved parties know about the finite nature of extractive projects, questions regarding the long-term future remain virtually unacknowledged. In this context, we can clearly state that power is primarily exercised by corporations and the government. While value undoubtedly is created by valorizing nature and exporting lithium to a global market, little value is actually captured for the long-term benefit of local people.
In the South American lithium triangle (Argentina, Bolivia and Chile), lithium is extracted together with other salts such as potassium and magnesium as a brine solution. The brine is pumped from cavities below the surface of Salars into large evaporation pools. Using solar evaporation to increase the relative lithium concentration, it takes about 12-24 months to obtain a solution ready to be processed to lithium carbonate (see Kavanagh et al., 2018). In contrast to lithium extraction from spodumenes, brine extraction is generally less energy-intensive and implies an important cost advantage. At the same time, it is severely criticized for using the region's scarcest resource in large quantities: water. According to Henríquez (2018), in the Chilean Salar de Atacama, the two companies SQM and Albemarle together extract more than 200 million liters of water per day (total of brine and fresh water), thus for each ton of lithium extracted, about 2 million liters of water evaporate.

In the entire Puna de Atacama, water is not only important for traditional economic activities but also culturally relevant. It is the basis for the existence of life in the world's most arid high-mountain region (the aridity of this ecosystem has already been described by Troll, 1968). While there is certainty that the inhabitants' employment will sooner or later have an expiry date, the environmental consequences for this highly fragile ecosystem remain inestimable. One government employee states that "actually nobody really knows the impacts that this activity is going to have. This is why everybody continues doing the same thing" (Interviewee 84). While the winners of lithium extraction are primarily nonplace-based actors, this statement points out how place-based actors are likely to suffer from long-run ecological repercussions.

\subsection{Soy agribusiness in Mato Grosso, Brazil}

The second case study of this article refers to the soybean production area in the north of the Brazilian state of MatoGrosso along the BR-163 highway (see Fig. 1). With a soy production of 31.6 million $t$ and a soy cultivation area of 9.4 million ha, Mato Grosso is Brazil's state with the largest soy production (reference year 2018, figures based on IBGE, Produção Agrícola Municipal). The research focus area lies within a transition zone between the Brazilian savanna, the so-called Cerrado and the Amazon rainforest biome.

Until the 1970s, northern Mato Grosso was almost exclusively inhabited by indigenous groups and was not subject to greater environmental transformations. This changed when the region became strategic for national plans of integrating the Brazilian periphery into the national economy during the Brazilian military dictatorship (1964-1985). The expansion of the pioneer and agricultural frontier was facilitated by the state through large-scale infrastructure projects (especially the construction of highways) accompanied by specific programs for regional development. In colonizing the region, the state pursued a dual strategy: on the one hand, land should 
be made available for small-scale farmers and landless people, thus counteracting land concentration and land conflicts in the agricultural core areas in the South and Northeast of Brazil. On the other hand, the state intended to lure private capital of investors, landlords and capitalized farmers by offering generous subsidized loans and tax incentives (e.g., tax exemptions for private companies) for the purchase of large land properties. In the north of Mato Grosso, the state sold large land areas to private colonization companies, which, in turn, subdivided the acquired areas into lots of different sizes and sold them through land brokers to medium- and smallscale farmers (Coy et al., 2017a).

The colonization of northern Mato Grosso was accompanied by far-reaching land use changes. As of the 1980s, mechanized monocultural soybean production began to expand quickly, especially in the Cerrado regions of the research area. Soy was considered a strategic crop in the efforts of modernizing agriculture in the expansion areas. Although already commercially cultivated in Brazil's southern states since the 1960s, it was now massively supported by the state's agricultural policies. The groundwork for soy cultivation in the tropical region of the Brazilian Cerrado was laid by investments in agricultural research, primarily expressed by the foundation of the Brazilian Agricultural Research Corporation (Empresa Brasileira de Pesquisa Agroepecuária, EMBRAPA) in 1972. EMBRAPA developed soybean varieties adapted to tropical soils and the climate of the Cerrados. Agricultural modernization and the cultivation of soybeans was further fostered by subsidized credits and through agricultural extension in the course of specific programs for agricultural development in the Cerrado (e.g., POLOCENTRO and PRODECER). On the high plateaus of the Cerrado regions, mechanized soybean cultivation quickly gained a foothold since the plain relief is particularly suitable for mechanized agriculture. Due to the lower biomass of the Cerrado in comparison to the forest of the Amazon biome, deforestation took place at a higher speed. This resulted in an availability of large land areas suitable for mechanized agriculture. As a consequence, more migrants (also more capitalized ones) from the south were attracted to move to the region, where they could acquire large land areas for relatively cheap prices (Fearnside, 2001).

Initially, the state played a leading role in the development of the agri-industrial complex in the Cerrado. However, in the course of the neo-liberal politics of the 1990s and during neo-extractivism in the 2000s, the state increasingly moved to the background, assuming the role of a facilitator for agribusiness expansion. Therefore, the regional soybean economy became increasingly driven by strategies of big agribusiness companies. Regional soybean expansion coincided with the rising demand for soy for animal feed in a globally rising oilseed-grain-livestock complex (Weis, 2013) and, to a smaller extent, for the rising demand of biofuels (biodiesel). China especially stands out within the global demand patterns for soybeans. The country became a net im- porter of soybeans in the 1990s and now accounts for more than $60 \%$ (FAOSTAT, 2020, data base year 2017) of the total quantity of the world's soybean imports.

In the area, soybean producers are principally migrants from southern Brazil. Some farmers were able to concentrate significant amounts of land by purchasing land from other settlers who could not keep up with the advance of modernized agriculture and by acquiring new agricultural land, which became available through the continuing agricultural expansion into natural vegetation. Although the region is mainly dominated by medium-scale soy producers (cultivating 1000 to $2500 \mathrm{ha}$ ), the largest soy producers accumulate several farms, reaching acreages of more than 50000 ha. In addition to these "regionally grown" soy producers, in recent years there has also been an increase in land control (through land purchase and land lease) of soy producers from other regions (from Brazil and from abroad) that externally manage their soy farms in the region. The growing influence of capital-backed farm management companies is changing land ownership structures in the region and increasingly prompting independent soybean farmers to sell or lease their land to these large investors (an illustrative example of such an expanding farm management company in the study region is the company Bom Futuro; see Théry, 2014). Moreover, to increase profit margins large soy-producing companies try to vertically integrate GPN activities within their own business. However, farm upstream and downstream activities are controlled by transnational agribusinesses. Regarding upstream activities, soybean farmers depend on the so-called technological package consisting of (GM) seeds, pesticides and fertilizers, which is provided by transnational agrichemical firms. These firms trade their products directly or indirectly, through retailers or in collaboration with grain traders, to the farms. Concerning the downstream sector, farmers depend on few transnational grain traders that control the global soy trade. In Mato Grosso only six traders control more than $60 \%$ of the soybean export. While Amaggi is a Mato Grossobased agribusiness company, the other big grain traders are corporations with headquarters in the USA (ADM, Bunge, Cargill), Europe (Louis Dreyfus) and China (Cofco). These soy traders became important regional actors not only because of their importance for exports, but they also turned into important providers of transport infrastructure and became the main operators of the soybean processing industry (soybean crushers) in the region.

The direct employment effects within soybean production are rather small, since a highly technological and mechanized production model, the so-called "precision agriculture", allows cultivating large land areas with a small workforce. The workers additionally need to have some kind of specialization and know-how in order to operate technologically complex production processes (operating machinery, application of agri-chemicals, etc.). However, the regional soybean economy creates more jobs outside the farm. Richards et al. (2015) assume that in Mato Grosso "soybean produc- 
tion supports 2.5 formal sector jobs outside of agriculture". Farm upstream activities include financing (banks, credit cooperatives); consultancy (private agricultural consultants, IT services, etc.); and retailing of agricultural machinery, vehicles, and agrichemical inputs, as well as the maintenance and repair sectors. Farm downstream activities are linked to warehouse logistics, processing industries, trade and transport logistics. This shift of activities from farm to extrafarm activities is accompanied by urbanization processes, as employment opportunities and agri-industrial activities are mostly found in urban rather than rural areas (Coy et al., 2019).

Undoubtedly, the soybean economy is the region's economic driving force and there is value captured in the region (see also Richards et al., 2015; Garrett and Rausch, 2016). However, the regional agribusiness model remains highly dependent on external factors. Even though some regionally embedded agribusiness players have achieved economic wealth and political power (on regional and national level) to steer regional development in the interest of the regional agribusiness economy, economic regional development continues to be highly dependent on global markets and business decisions and strategies taken at the executive levels at the headquarters of transnational corporations. Additionally, although the region is dominated by a success discourse of soybean-based agribusiness, this conceals other socio-ecological costs of the soy boom.

In international environmental and climate debates, the Brazilian soybean expansion is often portrayed as one of the main drivers for deforestation of the Amazonian forests. Less present is the fact that soybean expansion has mainly taken place in the Cerrado and has contributed to large-scale deforestation within this biome (de la Vega-Leinert and Huber, 2019). Although soybeans also expand to the Amazon, here it has a more indirect than direct influence on deforestation (Baletti, 2014). In the study area, soybean expansion into the Amazon region usually occurs through successive land use change, where the deforested areas are first used for smallscale agriculture or pastures (Richards et al., 2014). The conversion of large-scale cattle farms is a process through which soybean production expands into the Brazilian Amazon. The ongoing expansion and extensive use of land by the soy economy has contributed to a deepening of struggles over land for peasants and traditional communities (Sauer, 2018). Moreover, the heavy use of pesticides has led to further environmental pollution and health issues (Arvor et al., 2017). Additionally, the emergence of socially deprived neighborhoods in urban regions shows that not everyone benefits from the soybean boom. Such socio-environmental consequences need to be considered in order to reflect the real impact of regional integration on global soy production networks and to distinguish those who take benefits of soybean agribusiness expansion from those who bear the socio-environmental costs.

\section{Discussion}

Although every GPN is eventually based on the valorization of nature, the manufacturing sector is much more subject to human control than the primary sector, as it rests on the transformation of already produced raw material inputs through labor. In contrast, the primary sector relies on a strong dependence on and interaction with the biophysical world and is unavoidably constrained by natural forces. Within the primary sector, cultivation and extraction are ultimately "nature-based industries". However, they constitute "two fundamental logics of production" (Boyd et al., 2001). An extractive logic implies no control over natural production. Material production and actual labor occur with a strong time shift. To extract material formed naturally in the past, firms have to adapt their production strategies to specific natural requirements. Instead, a cultivation logic provides the opportunity to effectively manipulate natural processes (e.g., genetically modified soybeans). The actual production occurs after the employment of labor (see Bunker, 1989; Boyd et al., 2001).

The extractive logic and cultivation logic (with an extractivist character) can clearly be observed in the context of lithium mining and soybean production. Next to differences regarding the relation between production and labor, we can identify several resource-specific varieties of the respective GPN's manifestation. In the context of lithium mining, the influence on the production process is very low. In the first place, firms are limited to the mere extraction of brine. In a second step, the lithium brine is then concentrated through solar radiation. While the latter can potentially be sped up by human innovations, from a certain level onwards the extraction process is beyond the human sphere of influence. Furthermore, the evaporation process can be delayed through rain or snowfall and with a mine shutdown; as shown by the region's history, mining projects often have an abrupt date of expiry.

In contrast, soybean cultivation is a more spatially extensive process with a higher degree of influence on the production process itself. Based on GM seeds, chemical fertilizers and direct seeding techniques farmers were able to greatly raise yields and revenues in the past decades. However, both extraction and cultivation are eventually activities deeply rooted in natural processes. While the extraction regarding lithium appears obvious, the extraction of nutrients and water seems to be a more invisible but still inevitable process. Therefore, based on the depletion of soils that are difficult to recover, soybean cultivation has a more insidious expiry date without a specific endpoint.

The soybean GPN is controlled by global oligopolies. While transnational companies are positioned around the production process, soy producers maintain a certain degree of independence regarding the organization of farm production. Through large-scale land control the regional economic and political elite of soy producers accumulated a 
great amount of wealth. Although the major benefit is captured by TNCs, in northern Mato Grosso we can also identify groups of local profiteers. Moreover, the regional soybean economy directly and indirectly provides jobs of varying qualities. Nonetheless, the strong presence and the apparent success of the soy economy tends to obscure accompanying negative consequences. Traditional communities and peasants were largely expelled by the pervasive expansion of soybean cultivation. Alternative rural livelihoods and agricultural production systems with low ecological impact were and are displaced by large-scale soybean farming. Thereby, the soy expansion continues to trigger direct and indirect deforestation dynamics.

Instead, with respect to lithium mining, TNCs are directly involved in the production process. They are equal producers, so that the benefit is, seen relatively, more drastically captured by the companies themselves. Local profiteers are principally local entrepreneurs, characterized by a great dependence on the mining companies. Due to the relatively small surface needed for extraction, the losers are yet less obvious. Nonetheless, pastoralists in the immediate vicinity of the Salar already suffer effects such as resettlement, noise or water deficiency. In both cases, the economic activity causes environmental degradation and benefits are shared unequally.

\section{Conclusion}

Development questions, although often not precisely defined, are central concerns both for GPN and for PE literature. Both the GPN approach and the PE perspective show respective strengths for decoding - often ambiguous - development outcomes at the local level. While GPN offers deep insights into the organization of firms and production, PE focuses on the unequal distribution of resources and environmental risks. We argue that integrating a PE perspective into the global production network approach, particularly regarding the primary sector allows for a more differentiated and more critical perspective. In this article we have sought to outline initial theoretical and conceptual considerations for such an integrative perspective, which should provide impetus for further research in this direction. In a context of resource extraction, we cannot examine the international organization of production and extraction and the political framework as a self-sufficient category but also have to take into consideration the influence of noneconomic actors and environmental aspects. Analyzing local "development" in situations of resource extraction without bearing in mind the unevenly distributed environmental risk and the possibility of a mine shutdown or soil depletion offers only limited and short-sighted findings.

While in our research areas both soybean cultivation and lithium mining are predominantly seen as inevitable imperatives for economic growth, and in this respect are often celebrated as success stories, a more holistic contempla- tion reveals the emergence of small and powerful elites, the formation of unilateral dependencies, and a decline of social autonomy. Although value is undoubtedly created, little value can effectively be captured for the long-standing wellbeing of the respective region. Moreover, the consequences of ecological change present severe challenges for local food sovereignty and long-term human livelihood.

In this article, we have shown that applying the GPN approach to the primary sector requires a more holistic vision of global production networks themselves. While adapting and enhancing GPN analysis with additional or substituted conceptual categories presents a rather feasible task, the alignment and adjustment of the vague and fuzzy development concept remains an especially critical challenge for future research agendas.

Data availability. No data sets were used in this article.

Author contributions. The presented framework (Sect. 2) is based on a joint idea of FMD and $\mathrm{CH}$. FMD contributed case study $1, \mathrm{CH}$ study 2 .

Competing interests. The authors declare that they have no conflict of interest.

Acknowledgements. The authors gratefully acknowledge Lukas Dorn for language proofreading. We would like to thank the two anonymous reviewers for their helpful comments.

Financial support. Felix Dorn's research has been funded by the Marietta Blau grant of the Austrian Federal Ministry of Science and Research and the doctoral scholarship of the University of Innsbruck. Christoph Huber is a recipient of a DOC Fellowship of the Austrian Academy of Science at the Institute of Geography, University of Innsbruck. He is also grateful to the European Union for funding research mobility through the Horizon 2020 Research and innovation program ODYSSEA under Marie Skłodowska-Curie grant agreement no. 691053 .

Review statement. This paper was edited by Myriam HoussayHolzschuch and reviewed by two anonymous referees. 


\section{References}

Acosta, A.: Extractivismo y neoextractivismo: Dos caras de la misma maldición, in: Más allá del desarrolló, edited by: Lang, M. and Mokrani, D., Abya Yala, Quito, 83-120, 2012.

Altvater, E.: Der unglückselige Rohstoffreichtum: Warum Rohstoffextraktion das gute Leben erschwert, in: Umwelt und Entwicklung im 21. Jahrhundert: Impulse und Analysen aus Lateinamerika, edited by: Burchardt, H.-J., Dietz, K., and Öhlschläger, R., Nomos, Baden-Baden, 15-32, 2013.

Altvater, E. and Mahnkopf, B.: Grenzen der Globalisierung: Ökonomie, Ökologie und Politik in der Weltgesellschaft, 7th Edn., Westfälisches Dampfboot, Münster, 2007.

Arvor, D., Tritsch, I., Barcellos, C., Jégou, N., and Dubreuil, V.: Land use sustainability on the South-Eastern Amazon agricultural frontier: Recent progress and the challenges ahead, Appl. Geogr., 80, 86-97, 2017.

Baletti, B.: Saving the Amazon? Sustainable Soy and the New Extractivism, Environ. Plan. A, 46, 5-25, 2014.

Bauriedl, S.: Politische Ökologie: nicht-deterministische, globale und materielle Dimensionen von Natur/GesellschaftVerhältnissen, Geogr. Helv., 71, 341-351, https://doi.org/10.5194/gh-71-341-2016, 2016.

Blaikie, P. M. and Brookfield, H.: Land Degradation and Society, Longman, London, 1987.

Boyd, W., Prudham, W. S., and Schurman, R. A.: Industrial Dynamics and the Problem of Nature, Soc. Nat. Resour., 14, 555-570, 2001.

Bridge, G.: Global production networks and the extractive sector: governing resource-based development, J. Econ. Geogr., 8, 389419, 2008

Bridge, G.: Resource geographies 1: Making carbon economies, old and new, Prog. Human Geogr., 35, 820-834, 2010.

Bryant, R. L. and Bailey, S.: Third World Political Ecology. An Introduction, Routledge, Abingdon-on-Thames, 1997.

Bunker, S. G.: Staples, Links, and Poles in the Construction of Regional Development Theories, Sociolog. Forum, 4, 589-610, 1989.

Câmara, G., Picoli, M., Maciel, A., Simoes, R., Santos, L., Andrade, P. R., Ferreira, K., Begotti, R., Sanches, I., Carvalho, A. X. Y., Coutinho, A., Esquerdo, J., Antunes, J., and Arvor, D.: Land cover change maps for Mato Grosso State in Brazil: 2001-2017 (version 3), PANGAEA, https://doi.org/10.1594/PANGAEA.899706, 2019.

Castree, N.: Marxism and the production of nature, Capit. Class, 24, 5-36, 2000.

Coe, N. M., Dicken, P., and Hess, M.: Global production networks: realizing the potential, J. Econ. Geogr., 8, 271-295, 2008.

Coe, N. M., Hess, M., Yeung, H. W.-C., Dicken, P., and Henderson, J.: 'Globalizing' regional development: a global production networks perspective, T. Inst. Brit. Geogr., 29, 468-484, 2004.

Coy, M., Zirkl, F., and Töpfer, T.: Peripher und doch global vernetzt. Das brasilianische Agrobusiness und seine Folgen für räumliche Prozesse und Arbeitswelten, WSI-Mitteilungen, 72, 31-38, 2019

Coy, M., Klingler, M., and Kohlhepp, G.: De frontier até pós-frontier: regiões pioneiras no Brasil dentro do processo de transformação espaço-temporal e sócio-ecológico, confins,
30, available at: http://confins.revues.org/1168. (last access: 3 March 2017), 2017a.

Coy, M., Ruiz Peyré, F., and Obermayr, C.: South American resourcescapes: geographical perspectives and conceptual challenges, Erde, 148, 93-110, 2017b.

de la Vega-Leinert, C. and Huber, C.: The Down Side of CrossBorder Integration: The Case of Deforestation in the Brazilian Mato Grosso and Bolivian Santa Cruz Lowlands, Environ. Sci. Policy Sustain. Dev., 61, 31-44, 2019.

Dorn, F. M. and Hafner, R.: Re-primarization revisited: an analysis of decision-making variables in the Argentine soy agribusiness (1993-2015), Sustain. Debate, 9, 14-26, 2018.

FAOSTAT: FAOSTAT Database, Food and Agriculture Organization of the United Nations, Rome, 2020.

Fearnside, P. M.: Soybean cultivation as a threat to the environment in Brazil, Environ. Conserv., 28, 23-38, 2001.

Galeano, E.: Las venas abiertas de América Latina, 2nd Edn., Siglo Veintiuno, Buenos Aires, 2015.

Garrett, R. D. and Rausch, L. L.: Green for gold: social and ecological tradeoffs influencing the sustainability of the Brazilian soy industry, J. Peas. Stud., 43, 461-493, 2016.

Gereffi, G. and Korzeniewicz, M. (Eds.): Commodity Chains and Global Capitalism, Praeger Publishers, Westport, 1994.

Göbel, B.: La minería del litio en la Puna de Atacama: interdependencias transregionales y disputas locales, Iberoamericana, 13 , 135-149, 2013.

Gobierno de Jujuy: Impacto económico de la actividad minera en Jujuy, Ministerio de Desarrollo Económico y Producción, San Salvador de Jujuy, 2019.

Gudynas, E.: Agropecuaria y nuevo extractivismo bajo los gobiernos progresistas de América del Sur, Territorios, 5, 37-54, 2010.

Gudynas, E.: Debates sobre el desarrollo y sus alternativas en América Latina: Una breve guía heterodoxa, in: Más allá del desarrolló, edited by: Lang, M. and Mokrani, D., Abya Yala, Quito, 21-54, 2012.

Gudynas, E.: Beyond varieties of development: disputes and alternatives, Third World Quart., 37, 721-732, 2016.

Henderson, J., Dicken, P., Hess, M., Coe, N. M., and Yeung, H. W.-C.: Global production networks and the analysis of economic development, Rev. Int. Polit. Econ., 9, 436-464, 2002.

Henríquez, B. J.: Impacto socioambiental de la extracción de litio en las cuencas de los salares altoandinos del cono sur, OCMAL Observatorio de Conflictos Mineros de América Latina, Santiago de Chile, 2018.

Kavanagh, L., Keohane, J., Cabellos, G. G., Lloyd, A., and Cleary, J.: Global Lithium Sources - Industrial Use and Future in the Electric Vehicle Industry: A Review, Resources, 7, 1-29, 2018.

Kister, J.: Von Wachstum und Werten: Globale Wertschöpfungsketten im Fairen Handel, oekom, München, 2019.

Leff, E.: The power-full distribution of knowledge in political ecology: A view from the South, in: The Routledge Handbook of Political Ecology, edited by: Perreault, T., Bridge, G., and McCarthy, J., Routledge, Abingdon-on-Thames, 64-75, 2015.

Levy, D. L.: Political Contestation in Global Production Networks, Acad. Manage. Rev., 33, 943-963, 2008.

Machado Aráoz, H.: Potosí, el origen: Genealogía de la minería contemporánea, Mardulce, Buenos Aires, 2014.

McGrath, S.: Dis/articulations and the interrogation of development in GPN research, Prog. Human Geogr., 42, 509-528, 2018. 
McKay, B. M.: Agrarian Extractivism in Bolivia, World Dev., 97, 199-211, 2017.

Peet, R., Robbins, P., and Watts, M. (Eds.): Global Political Ecology, Routledge, Abingdon-on-Thames, 2011.

Petras, J. and Veltmeyer, H.: Extractive Imperialism in the Americas, Studies in Critical Social Sciences, 70, Brill, Leiden, 2014.

Pragier, D.: Comunidades indígenas frente a la explotación de litio en sus territorios: contextos similares, respuestas distintas, Polis - Revista Latinoamericana, 52, 1-20, 2019.

Radhuber, I. M.: Extractive Processes, Global Production Networks and Inequalities, Working Paper Series 89, desigualdades.net International Research Network on Interdependent Inequalities in Latin America, Berlin, 2015.

Richards, P., Pellegrina, H., VanWey, L., and Spera, S.: Soybean Development: The Impact of a Decade of Agricultural Change on Urban and Economic Growth in Mato Grosso, Brazil, PLoS ONE, 10, 1-18, 2015.

Richards, P. D., Walker, R. T., and Arima, E. Y.: Spatially complex land change: The Indirect effect of Brazil's agricultural sector on land use in Amazonia, Global Environ. Change, 29, 1-9, 2014.

Sauer, S.: Soy expansion into the agricultural frontiers of the Brazilian Amazon: The agribusiness economy and its social and environmental conflicts, Land Use Policy, 79, 326-338, 2018.

Schmitt, T.: Immer Ärger mit der Materialität? - Politische Ökologie und das Dispositiv der Dürre im Nordosten Brasiliens, Geogr. Helv., 71, 229-244, https://doi.org/10.5194/gh-71-2292016, 2016.

Schmitt, T. and Schulz, C.: Sustainable Resource Governance in Global Production Networks - Challenges for Human Geography, Erdkunde, 70, 297-312, 2016.

Smith, N.: Uneven Development: Nature, Capital, and the Production of Space, University of Georgia Press, Athens, Georgia, 1984
Svampa, M.: "Consenso de los Commodities" y lenguajes de valoración en América Latina, No. 244, Nueva Sociedad, Nueva Sociedad, ISSN 0251-3552, available at: https://nuso.org/articulo/consenso-de-los-commodities-ylenguajes-de-valoracion-en (last access: 22 June 2020), 2013.

Svampa, M.: Debates Latinoamericanos - Indianismo, desarrollo, dependencia y populismo, Edhasa, Buenos Aires, 562 pp., 2016.

Swyngedouw, E.: Social power and the urbanization of water: flows of power, Oxford geographical and environmental studies, Oxford University Press, Oxford, 2004.

Théry, H.: Un géant de l'agro-business dans le Mato Grosso, Espaço e Economia, 3, 1-14, https://doi.org/10.4000/espacoeconomia.1256, 2014.

Tortosa, J. M.: Maldesarrollo y Mal Vivir - Pobreza y Violencia a Escala Mundial, Abya Yala, Quito, 2011.

Troll, C.: The Cordilleras of the Tropical Americas. Aspects of climatic, phytogeographical and agrarian ecology, in: Geo-Ecology of the Mountainous Regions of the Tropical Americas, edited by: Troll, C., Ferd. Dümmlers Verlag, Bonn, 15-56, 1968.

Turzi, M.: The Political Economy of Agricultural Booms: Managing Soybean Production in Argentina, Brazil and Paraguay, Palgrave Macmillan, London, 2017.

Unceta, K.: Más allá del crecimiento - Debates sobre desarrollo y posdesarrollo, Mardulce, Buenos Aires, 248 pp., 2015.

Watts, M.: Imperial Oil: The Anatomy of a Nigerian Oil Insurgency, Erdkunde, 62, 27-39, 2008.

Weis, T.: The meat of the global food crisis, J. Peas. Stud., 40, 6585,2013

Yeung, H. W.-C. and Coe, N. M.: Toward a Dynamic Theory of Global Production Networks, Econ. Geogr., 91, 29-58, 2015. 